\title{
Metamorphism and deformation of mafic and felsic rocks in Bhavani Shear Zone, Tamilnadu, India
}

\author{
K. Rajaprian*, Kuldeep Singh, M. Vinoth Kumar, R. S. Kumar \\ Department of Earth Sciences, Annamalai University, Chidambaram, TN India \\ *Corresponding author E-mail: rajapriyangeo@gmail.com
}

\begin{abstract}
In southern India, Nilgiri block (NB) is separated from Western Dharwar Craton (WDC) and Palghat Cauvery Shear Zone (PCSZ) by Moyar and Bhavani shear zone (MSZ and BSZ) respectively. The Archaean high grade Bhavani shear is composed predominantly of meta-gabbro, meta-anorthosite and garnetiferrous gabbro, along with pyroxenite and amphibolites. The mafic rocks associated with hornblende gabbro and pyroxenite, retain magmatic structures and show evidence of major change in grain size and shapes granofelses of igneous relicts. The BSZ and MSZ are steeply-dipping thrusts, the Moyar shear in predominantly dip-slip transport. Gabbro majorly consists, assemblage of almandine-pyrope garnet and augite clinopyroxene as phenocryst with coexisting porphyroblasts texture. Geological structure relations combined with petrographical analysis from Moyar Bhavani shear zone (MBSZ) suggest that the gabbroic metamorphism was related to formation of the shear zone. Intermingled gabbroic rocks escaped metamorphism because they remained magmatic to lower temperatures, and experienced shorter and lower temperature sub-solidus cooling intervals. The felsic rocks underwent relatively high temperature solid-state deformation, as indicated by gabbro replacing K-felspar and subgrain patterns in quartz. The felsic rocks were deformed in the solid state because of their high proportion of relatively weak minerals (quartz and biotite), whereas, the mafic rocks mostly escaped sub-solidus deformation, except in local high-strain zone of their high proportion of relatively (hornblende and plagioclase) strong minerals.
\end{abstract}

Keywords: Amphibolite; Anorthosite; Bhavani Shear Zone; Pyroxenite; Garnet and Gabbro.

\section{Introduction}

The present study shows the evidence of metamorphism and deformation of mingled mafic-intermediate and felsic intrusive rocks in the upper portion of the BSZ, Tamilnadu (fig no 1). The South Indian shield considered to be a composite continental segment with diverse petrological, geochemical, structural and metamorphic characteristics; has witnessed several phases of ultra-basic, basic, acidic and alkaline magmatism, mainly in the Proterozoic and Late Palaeozoic eras (Bhattacharya et al. 2010). These rocks preserve a record of thermal gradients associated with partial melting, cooling, fractional crystallization, magmatic differentiation and emplacement that are useful in reconstructing tectonic histories (Widley et al. 1994). These intrusive bodies have been generally considered as post-tectonic especially due to the absence of mesoscopic fabrics, obscured contact relations and multiphase reactivation history of the associated shear zones (Rajesh et al. 2000).

The metamorphic microstructures of the mafic rocks were produced during slow cooling of magma and controlled by repeated local injection of sheeted igneous intrusive magma transfer zone. The mafic rocks resisted solid-state deformation (except in local high stress zones) because of an abundance of strong minerals (especially plagioclase and hornblende), whereas the felsic rocks deformed readily in the solid state because of an abundance of relatively weak minerals (especially quartz and biotite). Deformation of the mafic and felsic rocks occurred during and after repeated magma emplacement and cooling in a long-lived transtensional to trans-compressional shear zone, formerly re- ferred to as the Median Tectonic Zone (Bradshaw 1993, Kimbrough 1993, Kimbrough 1994). This information is central to models of the deep structure of creations the overall evolution of Archaean continents. It is seen that structural and denudational processes predominate over the fluvial processes. Then this resultant area is marked as plateau land forms, structural denudational and residual hills of charnockite and gneisses of linear ridge of basic dykes (Rajaprian et al. 2013). Lithosphere thickness and structure are deduced and questions bearing on the protolith and processes involved in the formation of lithosphere are addressed in the geochemical patterns recorded by garnets. These data provide some help on lateral and vertical changes of the study area; and may be helpful for petrological interpretation of lithosphere beneath of Archaean creation.

\section{Geological setting}

The BSZ, total length approximately $158 \mathrm{~km}$ and extended in Tamilnadu and Kerala (fig no 2). The present research has been carried out to facilitate the part of BSZ which falls in Tamilnadu state. Nilgiri block is separated to Cauvery Shear Zone (CSZ) by BSZ. The CSZ represents prominent Archaean-Proterozoic boundary in Southern Granulite Terrain (SGT), and exposes the highest-grade granulites of a prograde amphibolites facies to granulite facies deep-crustal section of Late Archaean age (Satyanarayanan et al. 2011). In the MSZ, deformation is shown by the ribbon quartz parallel to S-plane and in some instances by Boudinages in quartzofeldspathic layers in two directions parallel and perpendicular to lineation on the foliation plane wide variation 


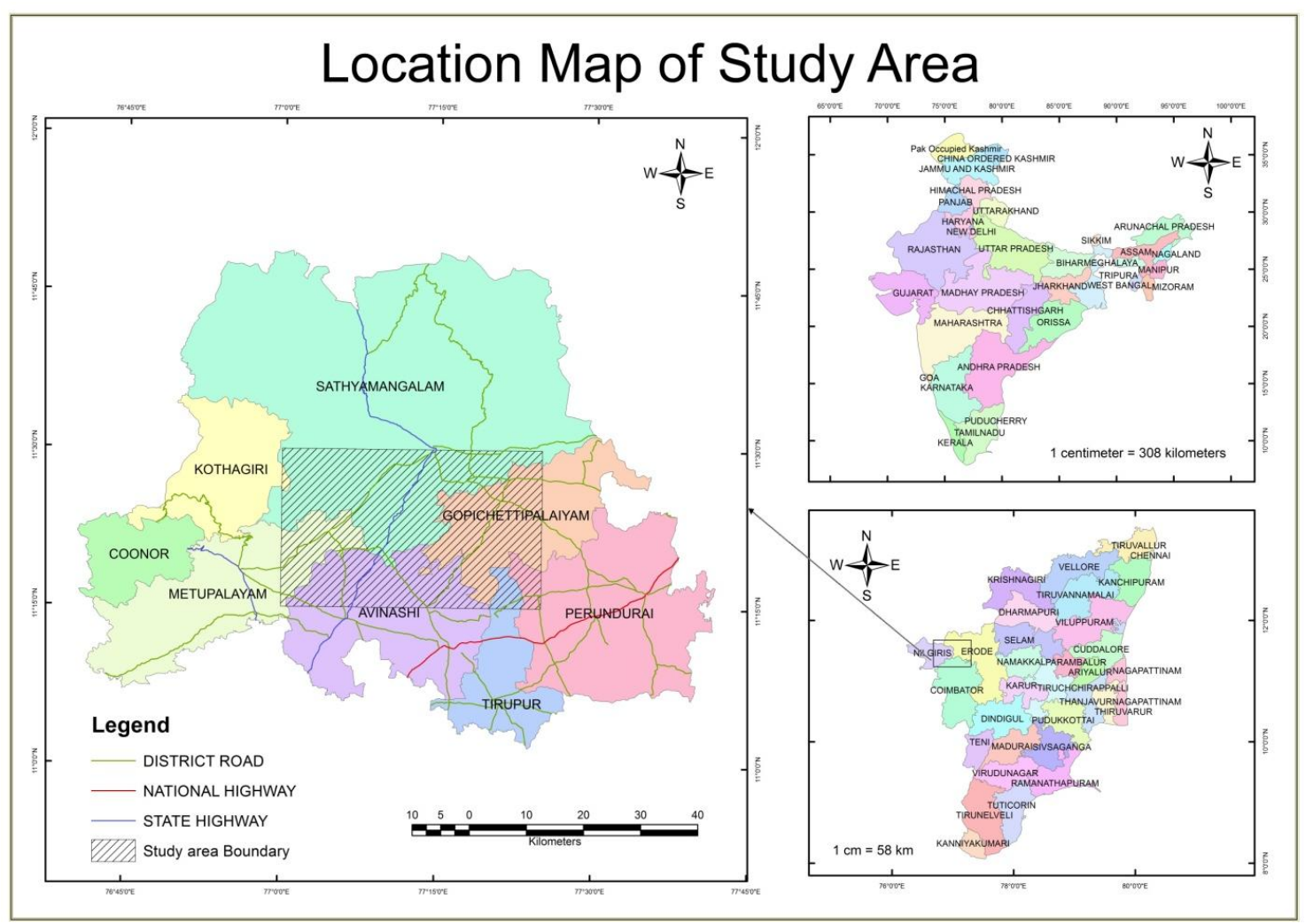

Fig. 1: Location Map of study area

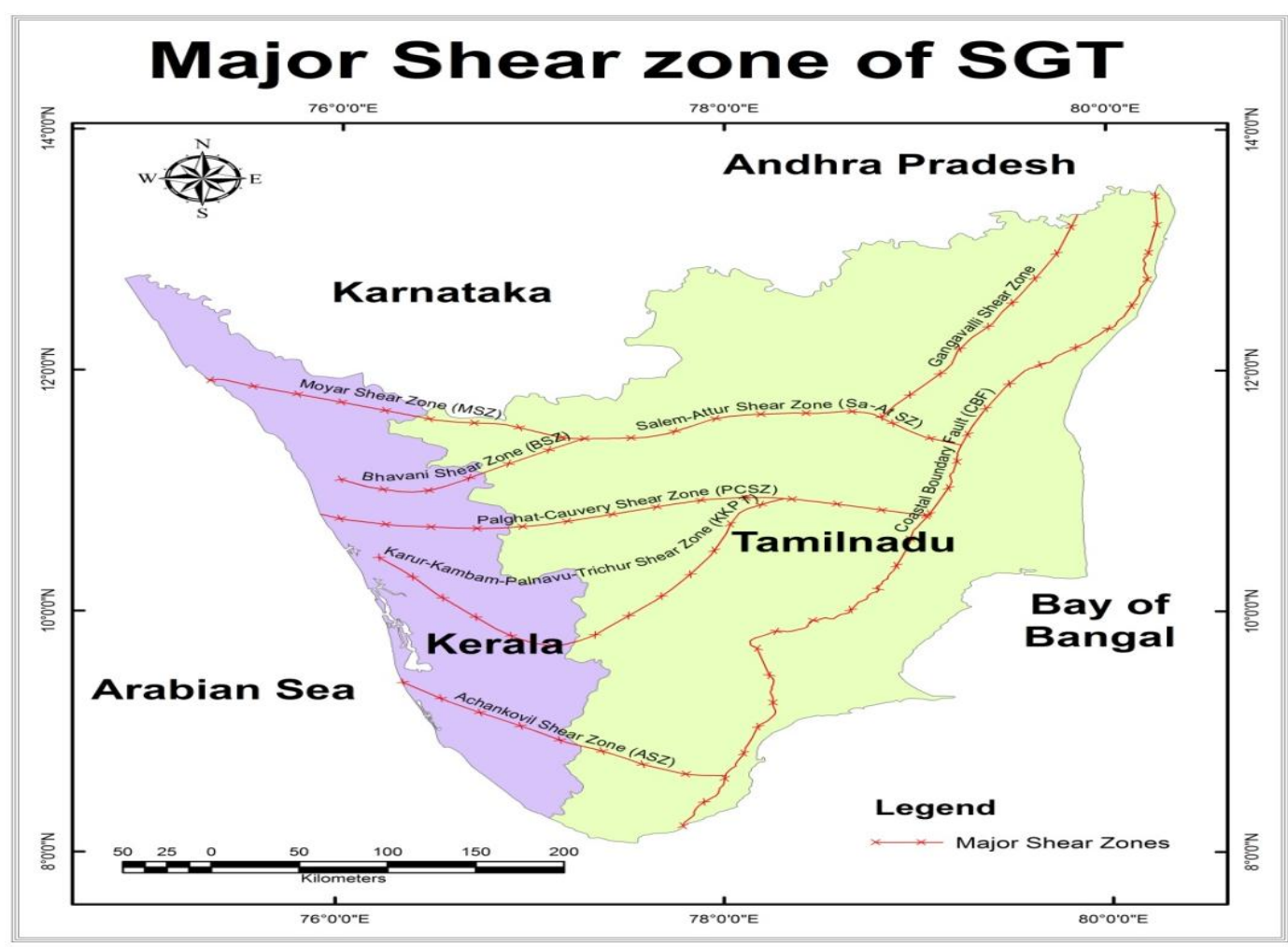

Fig. 2: Major shear zone of Southern granulite terrain (SGT) 


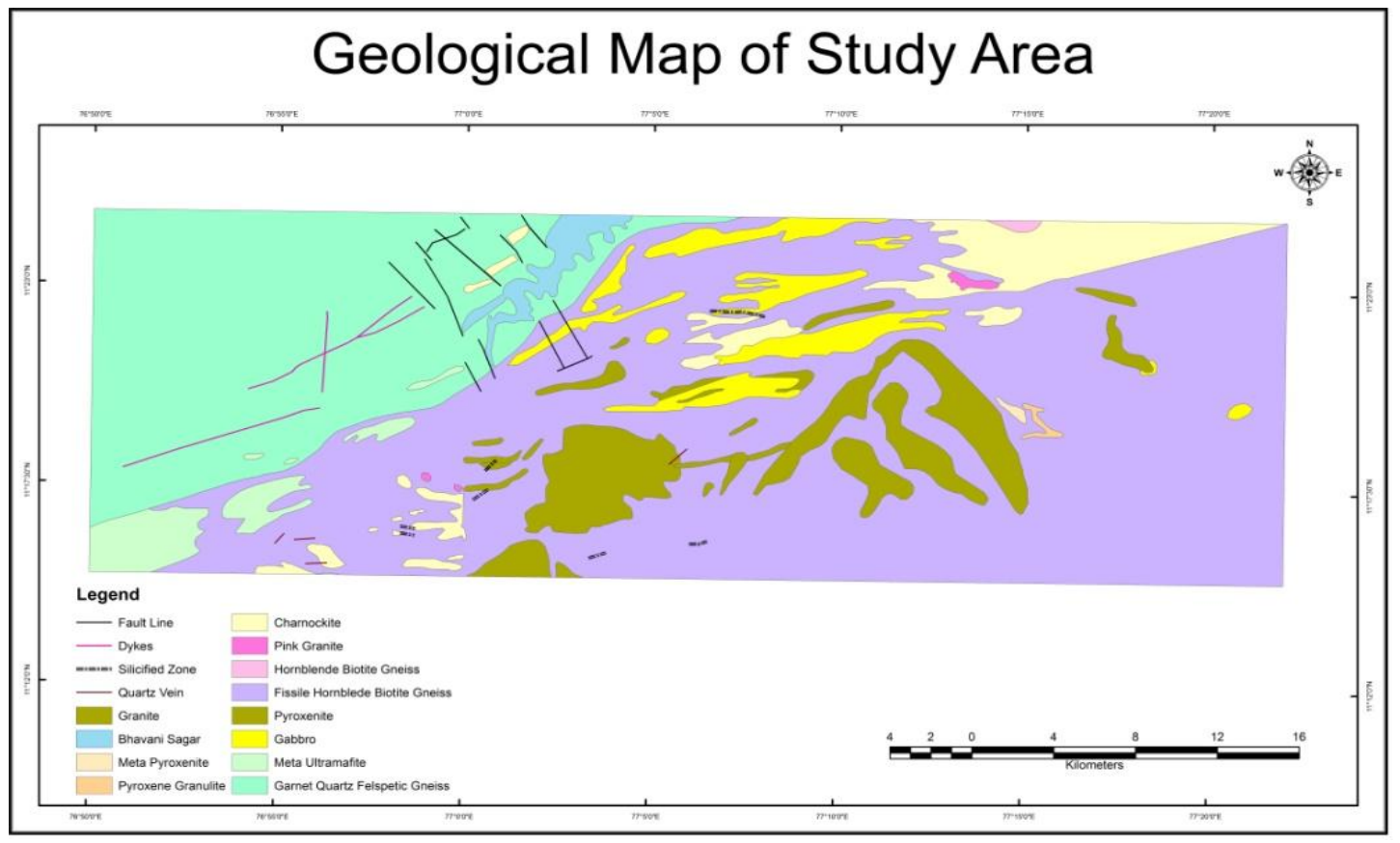

Fig. 3: Detailed geological map of study area

in strikes of foliation from $\mathrm{N} 70^{\circ} \mathrm{E}-\mathrm{S} 70^{\circ} \mathrm{W}$ and mesoscopic folds on sub-horizontal axes have been noted in the quartzofeldspathic gneisses.

In MSZ, more intensely deformation was observed approximately $4 \mathrm{~km}$ away from the Moyar village (Naha et al. 1996). The acid to basic intrusive and associated amphibolites, gneiss and mylonite form a part of the WNW-ESE trending MSZ, which extends along the northern fringes of the Nilgiri massif and joins the Palghat Cauvery Shear System (PCSS) (Pratheesh et al. 2010). The PCSZ refers to a series of major, largely E-W trending shear zones, Palghat, Cauvery, Moyar, Bhavani and Mettur that cross southern India (Drury et al. 1980). MSZ is more or less parallel to the roughly E-W trending gravity contours separating the gravity high and low between Cannanore and Mangalore (Krishna brahmam et al.1993). A discontinuous layer of migmatitic gneisses separates the peridotite body from the country rocks. Geological map describing (fig no 3 ) garnet occurs in one of numerous ultramafic lenses of ones to tens of centimeters in size, surrounded by gabbro and meta-gabbro, basic volcanics and gneisses and quartzites in part migmatitic gneisses, granite, pyroxenite.

The rocks show a granoblastic polygonal microtexture and display disequilibrium textures (like symplectitic coronas) mostly in metagabbroic rocks containing garnet (Subramaniam 1956, Janardhanan 1975, Selvan 1981, Rao 1996). Overprinting by retrograde hydrous minerals such as amphibole, clinopyroxene is prominent. Relict primary igneous textures and structures such as cumulate and compositional phase layering have been recognized in places permitting reconstruction of a generalized internal magmatic stratigraphy (Selvan et al. 1981). Texturally the hornblende is restricted to the cores of early formed, porphyroblastic, garnets are not found within other phases or in the common symplectites that occur between the coarse-grained minerals. Most of the mafic rocks are garnetiferous indicating its participation in the regional metamorphism, and micaceous amphibole rich rocks were found as enclaves while coarse grained pyroxenites were observed in between mafic rocks.

The light colored anorthositic gabbro is medium to fine grain with mafic segregations its show a flat E-W trending linear bodies showing sub-parallelism to the trend of main shear (Anbarasu et al. 2011).The regional structure is controlled by mutually parallel foliation and compositional layering, striking ENE-WSW and dipping moderately/steeply $\mathrm{N}$ or S. The BSZ exhibits both mesoscopic and microscopic features typical of deformation by ductile shearing under amphibolite facies conditions (Nair 1981, Cruz 2000). The ultrahigh-temperature granulites in the PCSZ have a U-Pb zircon metamorphic age of $530 \pm 4.9 \mathrm{Ma}$, monazite dates range from ca. 525 to $537 \mathrm{Ma}$, and inheritance ages are in the range of 2400-2600Ma (Collins et al.2007). Whilst mylonitic to ultra mylonitic fabrics characterize the bulk of these shear zones, there is a progressive increase in foliation intensity inwards towards their centers. In is transition can be classified into low (LS), medium (MS) and high (HS) strain regions, based on grain size reduction, elongation of polycrystalline quartz, feldspar, hornblendebiotite rich layers are shows increasing flattening result and increasing intensity of foliation development. Although these mylonitic regions are components of the main BSZ and represent already deformed rocks, on the scale of the minor shear zones, the LS regions can be considered as 'wall rock' whilst the MS and HS regions constitute 'shear zone' (Prasannakumar et al. 2010).

\section{Bhavani Intrusive}

In Bhavani area has numerous, relatively small, heterogeneous, commonly foliated intrusions of metagabbro, meta-anorthosite and gabbros, along with pyroxenite and amphibolites. At the several localities where sections were observed, then seem to graduate into each other, the dark-green micro-crystalline hornblendic rock becoming felspathic and light-colored, passing insensibly into it, though in one place it seems to penetrate it as a dyke. Mingling of mafic and felsic rocks is common (Cook 1988, Turnbull 2006, Turnbull 2010). It should be noted that although the focus on the application of lithostratigraphic terminology to Precambrian terrains, the general principles apply to any highly metamorphosed and/or intrusive-dominated rock succession, regardless of age (Easton et al. 2009). Some fine-grained mafic dykes in the granitoids grade along and across strike into zones of ovoid enclaves, implying mingling, as well as repeated injection of mafic magma (Allibone et al. 2004). These rocks have geochemical characteristics similar to pyroxenite; they were most likely formed in an extensional regime within a continent because they are associated with contemporary extensional tectonics (metamorphic core complexes), a type granites and peralkaline igneous rocks

The BSZ has a higher concentration of composite intrusive rocks. However, the change in foliation strike appears to be gradual, as mapped which could be interpreted as being due to progressive deformation and the different intrusion style could be due to repeated magma intrusion into a magmatic shear zone associated with pluton emplacement, the strike and dip of the mafic enclaves or sheets have different orientations from those of the rest of the rocks in Mettupalayam ultramafic complex (MUC). The BSZ, 
although well within the High-Grade Terrain (HGT), is largely made up of reworked gneisses which have a retro- grade relationship with the earlier chamockites. The crustal blocks which have escaped the shearing are preserved as charnockite massifs in the Nilgiri, Kolli and Shevroy hills. The gneisses in the region have an east-west trending planar fabric and have been highly deformed by polyphase folding with the interface of the north-south and eastwest deformation resulting in the formation of structural basin. This intrusive body is surrounded by Late-Archaean anorthosite and quartzo-feldspath gneiss to the north and west and charnockite to the east and south.

\section{Mafic ultrmafic granulites}

The mafic-ultramafic granulitic rocks cover a variety of rock types ranging from meta-gabbro, garnet-bearing to garnetiferous metagabbros. The basic granulites from the Bhavani and Sittampundi layered anorthosite complexes, lying within the PCSZ, have also yielded Sm-Nd whole-rock (WR) isochron ages of $2.899 \pm 0.028$ $\mathrm{Ga}$ and $2.935 \pm 0.060 \mathrm{Ga}$, indicating metamorphism of these bodies at $\sim 2.9 \mathrm{Ga}$ (Rao et al. 1996). The Moyar and the Bhavani shear zones in the southern India shield have often been used for tectonic and metamorphic interpretation on the assumption that there was a large strike-slip component during movement along these shear zone. High-grade rocks a few kilometres NE of Sittampund have $\mathrm{Rb}-\mathrm{Sr}$ metamorphic ages of 700-800 Ma, and the Cauvery shear zone underwent isothermal decompression of 4.5-3.5 kbar followed by high-temperature duration and retrogression at ca. $600^{\circ} \mathrm{C}$ (Allibone et al. 2004). Shear zones along the suture zone have Sm-Nd garnet crystallization ages of $624-521 \mathrm{Ma}$ and $\mathrm{Rb}$ $\mathrm{Sr}$ biotite cooling/uplift ages of ca.600-480 Ma (Deters-Umlauf
1998, Meibner 2002, Ghosh 2004). Plagioclase is never found as porphyroblasts in our samples, it occurs as symplectitic intergrowth with amphibole around garnet in association with both clinopyroxene and orthopyroxene. The peak metamorphic assemblages were later overprinted by retrogressed assemblage due to fluid influx and related hydration during decompression. Clinopyroxene pophyroblasts are altered to amphiboles along margins and those occurring as small inclusion in garnets are completely converted to amphiboles because of the fluid inflow along the cracks and fractures of the host garnet.

\section{Intrusive rocks}

The metamorphosed co-magmatic rocks of the Mettupalayam complex include a range of anorthositic variants that host pyroxenite bands and lenses of mafic-ultramafic granulites. Macroscopically, the Meta-gabbros are characterized by color indices greenish or dark-colored, with the mafic minerals being dominated by pyroxene, amphibole, and garnet. Plagioclase feldspar is the dominant light colored mineral in these rocks (Anbarasu et al. 2011). The Mettupalayam inferred the initial intrusion of a pyroxenite composed of hypersthene, diopsite and meta-gabbro, dunite and plagioclase felspar-bearing anorthosite followed by a heterogeneous suite formed in part by mingling of migmatite. Ultramafic rocks sheet-like bodies, ranging in thickness from a few centimeters to tens of meters, which intrude coarse grained pyroxenite. Some examples of local intrusion relationships, involving mafic, felsic and intrusive rocks, are shown in (Figs.4, AD).
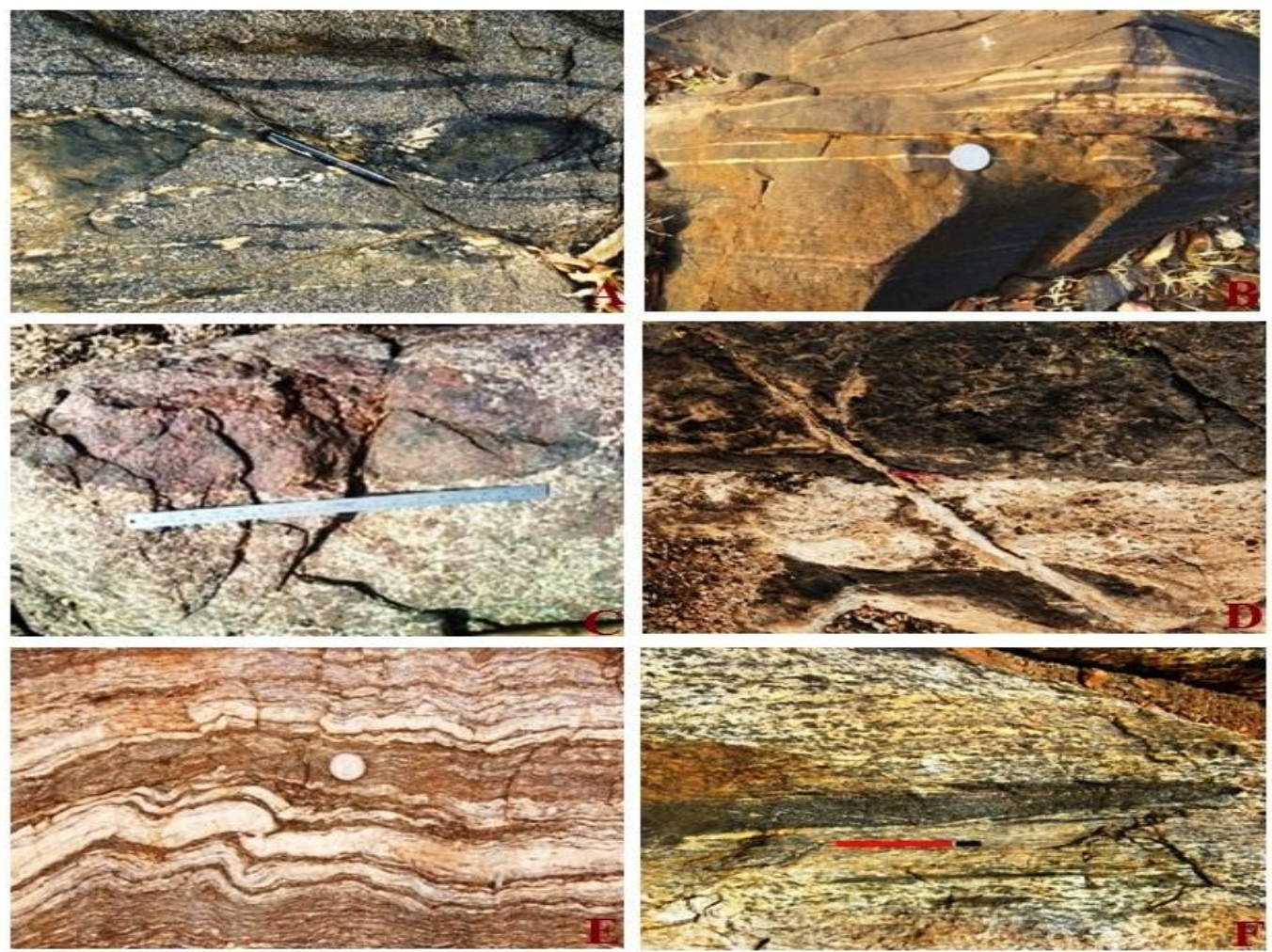

Fig. 4:

a) Transgressive mafic vein oblique to the foliation in deformed, mingled rocks. The mafic vein has been folded into a meta-gabbro high-strain zone. The curvature of the mafic fold indicates a dextral sense of rotation as viewed.

b) Felsic layer mingled unit cutting across earlier mingled ultramafic rocks. Felsic layers in the later intrusion of fine grain gabbro

c) Highly metamorphosed garnetiferous gabbro showing enclave of $42 \mathrm{~cm}$, lengh and breath $14 \mathrm{~cm}$, and more than a meter long the gneissic folia tion.

d) Mafic (pyroxenite) and felsic rock has been partly contact with more felsic rock (weathered anorthosite) and then intrusive layer of quartz vein.

e) Horizontal section normal to foliation in migmatitic gneiss in the Bhavani shear zone, with isoclinal folds indicating that the hanging wall has moved up relative to the footwall.

f) Mafic vein intrusion has been partly mingled with felsic rock (anorthosite) and then tightly flowing and locally transposed into a new foliation. 

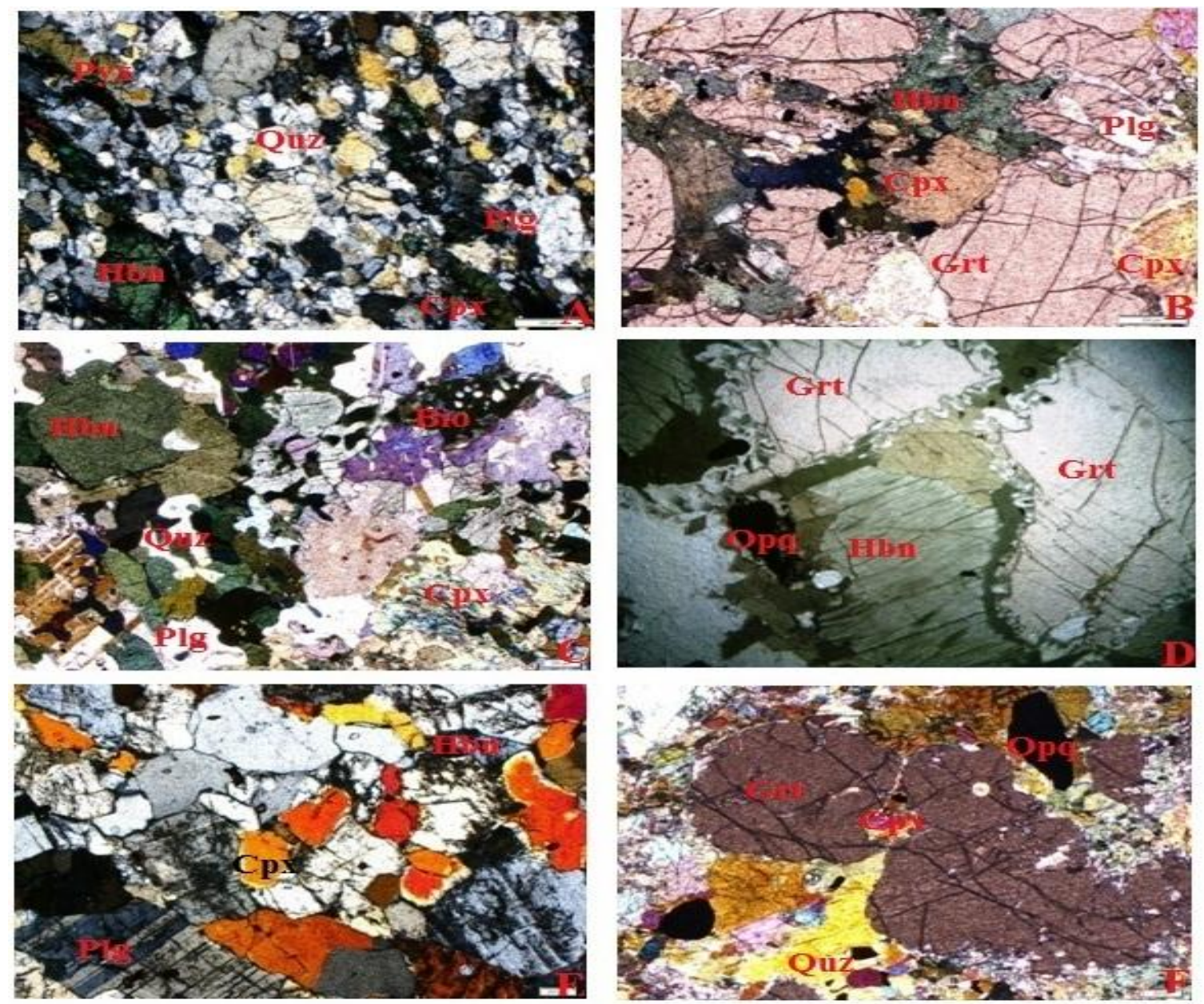

Fig.5:

a) Hornblende-plagioclase-biotite granofels (formerly a gabbro) consisting of polygonal grains with a few residual elongate pyroxenite shapes Crossed polarized light.

b) Hypidiomorphic texture in garnetiferrous gabbro, characterized by subhedral, zoned hornblende inclusions in garnet. Some of the plagioclase inclusions have rounded corners, and a few have rounded to irregular shapes. Crossed polarized light.

c) Granoblastic granular texture in gabbros of the area. Note the development of hornblende at the expense of clinopyroxene.

d) Photomicrograph of a meta-gabbro showing retrograded mineral assemblages. Grt: Garnet; Hbn: Hornblende; Opq: opaque mineral; Sym; Symplectitic intergrowth around garnet.

e) Anorthosite consisting mainly of plagioclase feldspar and hornblende, with local poikilitic intergrowths. The relatively well-developed curved plagioclase and plagioclase-hornblende boundaries. Crossed polarized light.

f) Porphyritic texture in garnet, characterized by subhedral, clinopyroxene inclusion in garnet.

Repeated intrusion of ultramafic highlights the repeated injection mode of emplacement in the higher levels of the Bhavani shear zone. Expansion of the EW-trending ultramafic set allowed injection of composite metagabbro, BSZ consisting of mingled mafic enclaves (Fig.4, A). The termination of the western part is marked by $\mathrm{S}-\mathrm{W}$ alignment of enclaves parallel to the termination and perpendicular to the general NW trend of enclaves, emphasizing that the enclave alignment is a magmatic flow foliation. The eastern margin of the ultramafic bodies shows incipient development of bridging structures, suggesting an encephalon arrangement, possibly associated with sinistral transtension. The archaean high grade Bhavani complex is composed predominantly of metagabbro and meta-anorthositic gabbros, along with pyroxenites and amphibolites. They are flat E-W trending linear bodies showing sub-parallelism to the trend of main shear (Satyanarayanan et al. 2011).The movement in the BSZ is thus in the nature of obliqueslip with the dip-slip component dominant. Folding and flattening of enclaves in the host-rock reflects increased viscosity of all intrusive phases during NE-SW shortening (Drury et al. 1984). BSZ straight margins also suggest a rigid host, which is emphasized further by still later narrow conjugate offsets. Hence, the outcrop provides evidence of an extended history of magma injection and cooling of the igneous-metamorphic complex during deformation. The ultramafic intrusions, many of which are only slightly transgressive to the dominant mafic-felsic layering (Figs.4. A, B, $\mathrm{D}, \mathrm{F})$, appear to have been intruded into the steeply dipping sequence, their general orientation being controlled by lithological anisotropies caused by the compositional layering, intrusion into the active stress high field.

\section{Metamorphism of mafic rocks}

\subsection{Alkali pyroxenite}

The alkali-pyroxenite is a dark colored coarse grained rock observed in Odhimalai Hill and Thenkalmalai Hill. The subhedral clinopyroxene grains are making up about $85 \%$ of the rock by volume and give rise to hypidiomorphic texture. Three distinct mineralogical assemblages viz. primary magmatic, vein-filling and post magmatic are observed in alkali-pyroxenite. Such mineralogical assemblages indicate micro scale metasomatic changes consanguineous to the felsic intrusion. Metabasites studied, clinopyroxene and orthopyroxene occur exclusively in the granulite faces zones. Both pyroxenes obviously were formed simultaneously at the transition from the amphibolite to granulite facies (Raase et al. 1974). The primary magmatic mineralogical assemblage is dominated by the diopsite pyroxene with significant hypersthene component and $\mathrm{Mg}-\mathrm{Fe}$ amphibole of hornblende type 
(fig no 5). The alteration of the primary mineralogical assemblages by the late stage vein-filling assemblages indicates magmatic alteration similar to the felsic intrusion.

\subsection{Garnetiferrous gabbro}

The formation of garnet is restricted to the granulite facies terrain and the southernmost part of the amphibolites zone, where it only occurs in metabasites of Fe-rich bulk composition (Raase et al 1974).This is finer grained, dark colored rock and characterized by the presence of garnet. In thin section, it shows hypidiomorphic granular texture with plagioclase mostly in subhedral and garnet in anhedral grains. In contrast to the first type, the plagioclase of this rock is relatively fresh without much alteration. Further, some grains are either untwined or not prominently twinned. It is more calcic in composition with an anorthoite content of $65-70 \%$ and is thus of labradorite range. The garnet is light brown in colour and is always anhedral and cuneiform. The presence of this mineral imparts a peculiar texture to the rock in thin section. The close spatial association of the mafic garnet-pyroxene granulites and charnockitic rocks with polyphase hornblende-biotite bearing gneisses and migmatites must be related to a local variation of the fluid phase composition. Therefore, amphibolite-granulite boundary reflects both the decrease in the water activity and the regional increase in temperature (Raase et al. 1974).Occasionally it formed narrow rims around larger crystals of plagioclase giving the appearance of atoll garnet. Also, it encloses smaller grains of plagioclase. Hornblende is subhedral to anhedral and pleochroic from yellow to bluish green. It occurs both as an alteration mineral of garnet and as an independent constituent. It forms pseudomorphous rim after garnet around plagioclase. It also occurs as a synantectic mineral at the contacts of ore and plagioclase.

\subsection{Garnet pyroxene (relict) amphibole rock}

These are greenish black rocks studded with pinkish-red grains of garnet. Weathered specimens appear to be studded with garnets owing to differential weathering, giving the impression that the rocks are composed wholly of garnet. Hand specimens have a holocrystalline texture without foliation. Megascopically the ultrabasic rocks is dark color and composed of chiefly of ironmagnesium silicates-olivine and pyroxene with small admixtures of secondary minerals, which is coarse to medium grained and small grains of amphibole (Rajaprian et al. 2014).Thin section show granoblastic texture with rounded grains of garnet surrounded by kelyphitic rims and interstitial amphibole. Amphibole within the greenschist and amphibolites facies zones, the development of the metabasite assemblages is characterized by progressive growth and compositional re-equilibration of amphibole (Raase et al. 1974). The orthopyroxenes from the chilled marginal zones of the intrusion, were determined from measurements of $a$ and $y$ on a separated sample of the pyroxene, and referring to the graph of (Poldervaar et al.1951). Relict clinophyroxene and orthophyroxene have continuation of phases with amphibole. The garnets are characterized by a system of horizontal cracks. Some sections display a crystalloblastic texture, with garnet embedded in a matrix of pyriboles and occasional plagioclase (fig no 5, B, F).

\section{Conclusion}

The BSZ is showing mafic and felsic rocks contrasting metamorphic and deformation effects. The magmatic precursors of the Bhavani layered complex are tholeiitic basalts produced at destructive plate margins or within plate tholeiites contaminated by continental crust. Both mafic and felsic rocks show evidence of magmatic flow. Many of the mafic rocks underwent to amphibolite facies metamorphism, whereas the felsic rocks avoided metamorphism, apart from the formation of local migmatite. We suggest that the steeply sheeted southern part of the BSZ in the magma transfer zone within the high grade tectonic zone of India. It is concluded that the unusual contrasting metamorphic and deformation effects between the mafic and felsic rocks provide microstructural evidence to discriminate magma transfer zone and a complex. We further suggest that the contrast could be diagnostic of longlived, magma-dominated transtensional BSZ that occur within the Earth crust and upper mantle of actively deforming magmatic arcs. The intercalated garnet granulites had an original mineralogy of garnet and clinopyroxene. These garnet granulites indicated that during the process of metamorphism, pressures should be nearly 8-10kbs. These bodies, in thin sections, often show good symplectitic textures. Garnets break down to a symplectite hornblende and plagioclase. The area has been subjected to high grade metamorphism and the mafic and ultramafic bodies occur as concordant lenses and sheets within the supracrustal gneisses.

\section{References}

[1] Bhattacharya S, Das P, Chaudhary A K and Saw A K. (2010): Mafic granulite xenoliths in the Eastern Ghats granulite belt: Implications for lower crustal processes in the southeastern Indian Peninsula; Indian J. Geol. 80, 53-67.

[2] Widley, B.F., Razafiniparany, A., Razakamanana, T. \& Ackermand, D. (1994): Tectonic framework of the precambrian of Madagascar and its Gondwana connections: a review and reappraisal, Geologische Rundschua, 83, 642-659.

[3] Rajesh, H.M. (2000): Characterization and origin of compositionally zoned aluminous A-type granite from South India. Geol. Mag., V.137 (3), 291-318

[4] Bradshaw, J.Y. (1993): A review of the Median Tectonic Zone: Terrane boundaries and terrane amalgamation near the Median Tectonic Line. New Zealand Journal of Geology and Geo- physics, 36, 117 126.

[5] Kimbrough, D.L., Tulloch, A.J., Geary, E., Coombs, D.S. \& Landis, C.A.(1993): Isotopic ages from the Nelson region of South Island, New Zealand: crustal structure and the definition of the Median Tectonic Zone. Tectonophysics, 225, 433-448.

[6] Kimbrough, D.L., Tulloch, A.J., and Coombs, D.S. (1994): Uraniumlead zircon ages from the Median Tectonic Zone, New Zealand. New Zealand Journal of Geology and Geophysics, 37, 393-419.

[7] Rajaprian, K., Kuldeep Singh., Vinoth Kumar, M., Kumar, R S. (2013): Geomorphic Features of the Mettupalayam Hills of Tamilnadu. Inventi Rapid: Water \& Enviroment Vol. Issue 4.

[8] Satyanarayanan, M., Balaram, V, Sylvester P.J., Subba Rao, D.V, Charan, S.N, Michael Shaffer, Ali Mohammed Dar and K. Anbarasu. (2011): Geochemistry of late-Archean Bhavani mafic/ultramafic complex, southern India: Implications for PGE metallogeny. Journal of applied geochemistry. Vol.13 No. 1, pp 1-14.

[9] Naha, K., Srinivasan, R. (1996) Nature of the Moyar and Bhavani shear zones, with a note on its implications on the tectonics of the southern Indian Precambrian shield. Proceedings of Indian Academy of Sciences 105, 143-189.

[10]Pratheesh, P, Prasannakumar V, And Praveen K.R.(2010): Mafic dykes of Moyar shear zone, North Kerala, India: Emplacement history and petrogenetic interpretation based on structure, geochemistry and magnetic fabric. The 1st International Applied Geological Congress, Department of Geology, Islamic Azad University Mashad Branch, Iran, 26-28 April.

[11]Drury, S.A., Holt, R.W. (1980): The tectonic framework of South Indian craton: a reconnaissance involving Landsat imagery. Tectonophysics 65, T1-T15.

[12] Krishna brahmam, N. (1993): Gravity in relation to crustal structure, palao-sutures and seismicity of Southern india (South of 16th parallel), Geol.Soc. Ind, mem., 25, 165- 201.

[13]Subramaniam, A.P. (1956): Mineralogy and petrology of the Sittampundi complex, Salem district, Madras State, India. Geological Society of America Bulletin 67, 317-390.

[14]Janardhanan, A.S., Leake, B.E. (1975): The origin of the metaanorthositic gabbros and garnetiferous granulites of the Sittampundi complex, Madras, India. Journal of Geological Society of India 16, 391-408.

[15]Selvan TA. (1981): Anorthosite-gabbro-ultramafic complex around Gobichettypalayam, Tamil Nadu and their possible relation to Sittampundi type anorthosite complex (unpublished). Ph.D. thesis Univ Mysore Mysore India.

[16]Rao YJB, Chetty TRK, Janardhan AS, and Gopalan K. (1996): Sm-Nd and Rb-Sr ages and P-T history of the Archean Sittampundi and 
Bhavani layered meta-anorthosite complexes in Cauvery shear zone,South India: evidence for Neoproterozoic reworking of Archaean crust. Contrib Mineral Petrol, 125:237-250.

[17] Anbarasu, K,. Ali Mohammed Dar, Karthikeyan, A,. Prabhu, D. (2011): Field characteristics and geochemistry of pyroxenite and gabbro from Odhimalai and Thenkalmalai hillocks of Bhavani ultramafic complex-South India. International Multidisciplinary Research Journal, $1 / 2: 2026$.

[18]Nair, P.K.R., Prasannakumar, V. and Thomas mathai. (1981): Structure of the western termination of the Bhavani lineament. Jour. Geol. Soc. India, V. 22, 1981, 285-291.

[19]Cruz. E.D., Nair, P.K.R. and Prasannakumar, V. (2000): Palghat Gapa dextral shear zone from the south Indian granulite terrain. Gondwana Res., V. 3, 21-31.

[20]Collins, A.S., Clark, C., Sajeev, K., Santosh, M., Kelsey, D.E., Hand, and M. (2007): Passage through India: the Mozambique Ocean suture, high pressure granulites and the Palghat-Cauvery shear zone system. Terra Nova 19, 141-147.

[21]Prasannakumar, V, And Geoffrey E. Lloyd.(2010): Application of SEM-EBSD to Regional Scale Shear Zone Analysis: A Case Study of the Bhavani Shear Zone, South India. Journal geological society of india.Vol.75, January, pp.183-201.

[22]Cook, N. D. J. (1988): Diorites and associated rocks in the Anglem Complex at the Neck, northeastern Stewart Island, New Zealand: an example of magma mingling. Lithos 21, 247-262.

[23] Turnbull, R. (2006): Mafic / Felsic magma mingling processes in the Bungaree Intrusives, Stewart Island, New Zealand. Geological Society of New Zealand Newsletter, 141, 33.

[24]Turnbull, R., Weaver, S., Tulloch, A., Cole, J., Handler, M. \& Ireland and T. (2010): Field and geochemical constraints on maficfelsic interactions, and processes in high-level arc magma chambers: an example from the Halfmoon Pluton, New Zealand. Journal of Petrology, 51, 1477-1505.

[25]Easton R. M. (2009): A guide to the application of lithostratigraphic terminology in Precambrian terrains, stratigraphy, vol. 6, no. 2, pp. 117-134.

[26]Allibone, A.H. \& Tulloch, A.J. (2004): Geology of the plutonic basement rocks of Stewart Island, New Zealand. New Zealand Journal of Geology and Geophysics, 47, 233-256.

[27]Deters-Umlauf, P., Srikantappa, C., Köhler, H. (1998): Pan-African ages in the Moyar and Bhavani shear zones (South India). Indian Mineralogist 32, 123-124.

[28]Meibner, B., Deters, P., Srikantappa, C., Köhler, H. (2002): Geochronological evolution of the Moyar, Bhavani and Palghat shear zones of southern India: implications for East Gondwana correlations. Precambrian Research 114, 149-175.

[29]Ghosh, J.G., de Wit, M.J., Zartman, R.E. (2004): Age and tectonic evolution of Neoproterozoic ductile shear zones in the Southern Granulite Terrain of India, with implications for Gondwana studies. Tectonics 23 (TC3006), doi: 10.1029/2002TC001444.

[30]Drury, S.A., Hariss, N.B.W., Holt, R.W. Reeves -Smith G.J., Wightman, R.T. (1984): Precambrian tectonics and crustal evolution in South India, J. of Geophysics, 92, 3-20.

[31]Raase P. (1974): Al and Ti contents of hornblende, indicators of pressure and temperature of regional metamorphism. Contrib Mineral Petrol, 45:231-236.

[32]Rajaprian, K, Kuldeep Singh,Vinoth Kumar, M,. Kumar, R S, (2014): Petrological and Major Oxide Geochemical Studies of Ultra Basic Rocks of Sirumugai and Adjoining Area, Tamilnadu. Inventi Rapid: Water \& Environment Vol. Issue 1.

[33]Poldervaar at. Andhess, H. H. (1951): Pyroxenes in the crystallization of basaltic magmas. J. Ceol., 59, 472-489. 